\title{
The specific inhibitory effect of demethoxydehydroaltenusin, a derivative of dehydroaltenusin, on mammalian DNA polymerase $\alpha$
}

\author{
ISOKO KURIYAMA ${ }^{1}$, KEISHI FUKUDOME ${ }^{2}$, SHINJI KAMISUKI ${ }^{2}$, KOUJI KURAMOCHI $^{3}$, KAZUNORI TSUBAKI $^{3}$, \\ KENGO SAKAGUCHI $^{2}$, FUMIO SUGAWARA ${ }^{2}$, HIROMI YOSHIDA ${ }^{1,4}$ and YOSHIYUKI MIZUSHINA ${ }^{1,4}$ \\ ${ }^{1}$ Laboratory of Food \& Nutritional Sciences, Department of Nutritional Science, Kobe-Gakuin University, Nishi-ku, \\ Kobe, Hyogo 651-2180; ${ }^{2}$ Department of Applied Biological Science, Tokyo University of Science, Noda, \\ Chiba 278-8510; ${ }^{3}$ Graduate School of Life and Environmental Science, Kyoto Prefectural University, Kyoto 606-8522; \\ ${ }^{4}$ Cooperative Research Center of Life Sciences, Kobe-Gakuin University, Nishi-ku, Kobe, Hyogo 651-2180, Japan
}

Received July 30, 2008; Accepted September 5, 2008

DOI: $10.3892 /$ ijmm_00000087

\begin{abstract}
In the screening of selective inhibitors of eukaryotic DNA polymerases (pols), dehydroaltenusin from the fungus Acremonium sp. was found to be an inhibitor of pol $\alpha$. The present study succeeded in chemically synthesizing dehydroaltenusin, and the compound strongly inhibited calf pol $\alpha$ activity and weakly suppressed rat pol $\mathrm{B}$ activity, with $\mathrm{IC}_{50}$ values of 0.68 and $64 \mu \mathrm{M}$, respectively. We purified or synthesized various slightly modified derivatives of dehydroaltenusin, and using these, investigated the relationship between chemical structure and the inhibitory effects. These results suggest that the ketone group at the 5'-position in dehydroaltenusin is essential for pol inhibitory activity, and the group at the 5-position is important for the specificity of pol $\alpha$ inhibition. Demethoxydehydroaltenusin was found to be the most specific pol $\alpha$ inhibitor among the prepared derivatives, and the $\mathrm{IC}_{50}$ values for pols $\alpha$ and $\beta$ were 0.24 and $89 \mu \mathrm{M}$, respectively. This compound did not influence the activities of other replicative pols such as pols $\delta$ and $\varepsilon$, and also demonstrated no effect on pol $\alpha$ activity from another vertebrate, fish and a plant species. Demethoxydehydroaltenusin also had no influence on the other pols and DNA metabolic enzymes tested. Therefore, demethoxydehydro-
\end{abstract}

Correspondence to: Dr Yoshiyuki Mizushina, Laboratory of Food \& Nutritional Sciences, Department of Nutritional Science, Kobe-Gakuin University, Nishi-ku, Kobe, Hyogo 651-2180, Japan

E-mail:mizushin@nutr.kobegakuin.ac.jp

Abbreviations: pol, DNA-directed DNA polymerase (EC 2.7.7.7); $\mathrm{IC}_{50}, 50 \%$ inhibitory concentration; dTTP, 2'-deoxythymidine 5'triphosphate; dNTP, 2'-deoxyribonucleotide 5'-triphosphate; HIV-1, human immunodeficiency virus type-1

Key words: demethoxydehydroaltenusin, dehydroaltenusin, DNA polymerase $\alpha$, enzyme inhibitor, chemical knockout agent, DNA replication altenusin is of interest as a mammalian pol $\alpha$-selective inhibitor as a 'chemical knockout agent' in vitro and in vivo.

\section{Introduction}

The human genome encodes 16 DNA polymerases (pols) that control cellular DNA synthesis (1). Eukaryotic cells reportedly contain three replicative types: pols $\alpha, \delta$ and $\varepsilon$, mitochondrial pol $\gamma$, and at least twelve repair types: pols $\beta$, $\delta, \varepsilon, \zeta, \eta, \theta, \iota, \kappa, \lambda, \mu$, and $\sigma$ and REV1 (2). Selective inhibitors of each pol are useful tools and molecular probes for distinguishing pols and for clarifying their biological and in vivo functions (3). For example, aphidicolin is a selective inhibitor of both pol $\alpha$ and eukaryotic DNA replicative pols $\delta$ and $\varepsilon$, indicating that these pols are essential for DNA replication (4), and this inhibitor has been very useful for studying the DNA replication system (5); however, aphidicolin is not capable of distinguishing pols $\alpha, \delta$ and $\varepsilon$.

Therefore, we established an assay method to detect pol inhibitors, and have screened for natural sources of inhibitors for more than 10 years. An inhibitor was isolated that selectively influences the activity of mammalian pol $\alpha$, dehydroaltenusin, from a fungus (Acremonium sp.) collected from fields in the vicinity of Noda city in Chiba prefecture, Japan (6). A total chemical synthesis method was established for dehydroaltenusin and succeeded in completely synthesizing the compound (7-9).

Subsequently, the slightly modified derivatives were purified or chemically synthesized to examine the structural relationship between dehydroaltenusin and pols. Dehydroaltenusin and its analogues represent a group of potentially useful agents to examine the precise role of each pol in vivo, and to develop a drug design strategy for cancer chemotherapy agents. The compounds can also be useful tools as molecular probes to study the three-dimensional structure of mammalian pol $\alpha$ protein.

\section{Materials and methods}

Materials. Nucleotides and chemically synthesized DNA template-primers such as $\left[{ }^{3} \mathrm{H}\right]-2^{\prime}$-deoxythymidine 5 '-tri- 
A<smiles>COc1cc(O)c2c(c1)C1=CC(=O)C(O)=CC1(C)OC2=O</smiles><smiles>COc1cc(OC)c2c(c1)C1=CC(=O)C(OC(C)=O)=CC1(C)OC2=O</smiles><smiles>CC12C=C(O)C(=O)C=C1c1cccc(O)c1C(=O)O2</smiles><smiles>COc1cc(O)c2c(c1)C1=CC(O)C(O)CC1(C)OC2=O</smiles><smiles>COc1cc(O)c2c(=O)oc3cc(O)c(O)cc3c2c1</smiles><smiles>COc1cc(O)c(C(=O)O)c(-c2cc(O)c(O)cc2C)c1</smiles><smiles>Cc1cc(O)cc2oc(=O)c3c(O)cc(O)cc3c12</smiles>

B<smiles>[R]c1cc(O)c2c(c1)C1=CC(=O)C(O)=CC1(C)OC2=O</smiles>

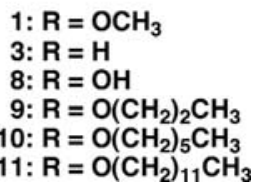

Figure 1. Chemical structures of dehydroaltenusin and its derivatives. (A) Core-modified dehydroaltenusin analogues. (B) Demethoxydehydroaltenusin derivatives modified at the 5-position. 1, Dehydroaltenusin; 2, acetyl-dehydroaltenusin; 3, demethoxydehydroaltenusin; $\mathbf{4}$, altenuene; 5, $6 H$-benzo $c]$ chromen-6-one derivative; 6, altenusin; 7, alternariol; 8, demethyldehydroaltenusin; 9, dehydroaltenusin-C3; 10, dehydroaltenusin-C6; and 11, dehydroaltenusin-C12.

phosphate (dTTP, $43 \mathrm{Ci} / \mathrm{mmol})$, poly $(\mathrm{dA})$, and oligo $(\mathrm{dT})_{12-18}$ were purchased from GE Healthcare Bio-Science Co. (Buckinghamshire, UK). All other reagents were of analytical grade and were purchased from Nacalai Tesque Inc. (Kyoto, Japan).

Preparation of dehydroaltenusin and its derivatives. Dehydroaltenusin $\mathbf{1}$ and altenusin $\mathbf{6}$ were synthesized chemically according to a previously reported method $(7,8)$. Acetyldehydroaltenusin 2 was prepared by acetylation of dehydroaltenusin-C3 9. Demethoxydehydroaltenusin 3 and a $6 \mathrm{H}$ benzo $[c]$ chromen-6-one derivative $\mathbf{5}$ were newly synthesized starting from 2,2-dimethyl-4-oxo-4H-1,3-benzodioxin-5-yl trifluoromethanesulfonate $(10,11)$ and 4,5-bis(benzyloxy)-2iodophenyl acetate (12), respectively. Altenuene $\mathbf{4}$ and alternariol 7 were isolated from the extract of Acremonium sp. (13). Demethyldehydroaltenusin 8, dehydroaltenusin-C3 derivative 9, dehydroaltenusin-C6 derivative $\mathbf{1 0}$ and dehydroaltenusin-C12 derivative $\mathbf{1 1}$ were prepared from a common intermediate, 7-hydroxy-2,2-dimethyl-5-(6-methyl1,3-benzodioxol-5-yl)-4H-1,3-benzodioxin-4-one. All new synthetic products were fully characterized by ${ }^{1} \mathrm{H}$ and ${ }^{13} \mathrm{C}$ nuclear magnetic resonance (NMR), infrared spectroscopy (IR) and high resolution mass spectrometry (HRMS). The chemical structures of dehydroaltenusin derivatives 1-11 are shown in Fig. 1. The synthetic details and characterization for all chemical derivatives will be reported elsewhere (Kuramochi et al, unpublished data).

DNA polymerases and other DNA metabolic enzymes. Pol $\alpha$ was purified from calf thymus by immuno-affinity column chromatography as described previously (14). Pol $\beta$ was purified from a recombinant plasmid expressing rat pol $B$ (15). The gene encoding the human pol $\gamma$ catalytic subunit was cloned into pFastBac. The histidine-tagged enzyme was expressed using the BAC-TO-BAC HT Baculovirus Expression System according to the manufacturer's instructions (Life Technologies, MD, USA) and purified using ProBoundresin (Invitrogen Japan, Tokyo, Japan) (16). Human pols $\delta$ and $\varepsilon$ were purified by the nuclear fractionation of human peripheral blood cancer cells (Molt-4) using the second subunit of pols $\delta$ - and $\varepsilon$-conjugated affinity column chromatography, respectively (17). Recombinant human pol $\eta$ and 1 tagged with $\mathrm{His}_{6}$ at their C-terminal ends were expressed in SF9 insect cells using a baculovirus expression system, and were purified from the cells as described previously $(18,19)$. A truncated form of pol $\kappa$ (i.e. hDINB1DC) with a $6 \times$ His-tag attached at the C-terminus was overproduced using the BAC-to-BAC Baculovirus Expression System Kit (Gibco BRL) and purified as described by Ohashi et al (20). 
Table I. IC I0 $_{50}$ values of core-modified dehydroaltenusin analogues on the activities of mammalian DNA polymerase $\alpha$ and $B$.

\begin{tabular}{lcr}
\hline Compound & \multicolumn{2}{c}{$\mathrm{IC}_{50}$ value $(\mu \mathrm{M})$} \\
\cline { 2 - 3 } & Pol $\alpha$ & Pol $\beta$ \\
\hline $\mathbf{1}$ & 0.68 & 64 \\
$\mathbf{2}$ & 7.40 & 48 \\
$\mathbf{3}$ & 0.24 & 89 \\
$\mathbf{4}$ & $>100$ & $>100$ \\
$\mathbf{5}$ & $>100$ & $>100$ \\
$\mathbf{6}$ & $>100$ & $>100$ \\
$\mathbf{7}$ & $>100$ & $>100$ \\
\hline
\end{tabular}

1, Dehydroaltenusin; 2, acetyl-dehydroaltenusin; 3, demethoxydehydroaltenusin; 4, altenuene; 5, $6 H$-benzo $[c]$ chromen-6-one derivative; 6, altenusin; 7, alternariol. These compounds were incubated with calf pol $\alpha$ or rat pol $\beta$ (0.05 units each). Enzyme activity in the absence of the compound was taken as $100 \%$.

Recombinant His-pol $\lambda$ was overexpressed and purified according to the method described previously (21). Fish pols $\alpha$ and $\delta$ were purified from the testes of cherry salmon (Oncorhynchus masou) (22). Pol I ( $\alpha$-like) from a higher plant, cauliflower inflorescence, was purified according to the methods outlined by Sakaguchi et al (23). Recombinant rice (Oryza sativa L. cv. Nipponbare) pol $\lambda$ tagged with $\mathrm{His}_{6}$ at the C-terminal was expressed in $E$. coli and purified from the cells as described by Uchiyama et al (24). The Klenow fragment of pol I from $E$. coli and human immunodeficiency virus type-1 (HIV-1) reverse transcriptase were purchased from Worthington Biochemical Corp. (Freehold, NJ, USA). Taq pol, T4 pol and T4 polynucleotide kinase were purchased from Takara (Kyoto, Japan). Purified human placental DNA topoisomerases I and II $\alpha$ were obtained from TopoGen, Inc. (Columbus, OH, USA). T7 RNA polymerase and bovine pancreas deoxyribonuclease I were purchased from Stratagene Cloning Systems (La Jolla, CA, USA).

DNA polymerase assay. The reaction mixtures for pol $\alpha$, pol $\beta$, fish pols, plant pols and prokaryotic pols were described previously $(25,26)$. Those for pol $\lambda$ and pols $\delta$ and $\varepsilon$ were as described by Umeda et al (16) and Ogawa et al (27), respectively. The reaction mixtures for pol $\eta, \iota$ and $\kappa$ were the same as that for pol $\alpha$, and the reaction mixture for pol $\lambda$ was the same as that for pol $B$. For the pols, poly $(\mathrm{dA}) /$ oligo $(\mathrm{dT})_{12-18}(\mathrm{~A} / \mathrm{T}=2 / 1)$ and $\left[{ }^{3} \mathrm{H}\right]$-dTTP were used as the DNA template-primer and nucleotide (i.e., 2'-deoxyribonucleotide 5'-triphosphate, dNTP) substrate, respectively. The substrates of HIV-1 reverse transcriptase used were poly(rA)/oligo(dT) $)_{12-18}$ and dTTP as the template-primer and nucleotide substrate, respectively. The dehydroaltenusin derivative was dissolved in dimethyl sulfoxide (DMSO) at various concentrations and sonicated for $30 \mathrm{sec}$. Four microliters of each sonicated sample was mixed with $16 \mu 1$ of each enzyme (final 0.05 units) in $50 \mathrm{mM}$ Tris- $\mathrm{HCl}(\mathrm{pH} 7.5)$ containing $1 \mathrm{mM}$ dithiothreitol, $50 \%$ glycerol and $0.1 \mathrm{mM}$ ethylenediamine tetraacetic acid (EDTA) and kept at $0^{\circ} \mathrm{C}$ for $10 \mathrm{~min}$. These inhibitor-enzyme mixtures $(8 \mu \mathrm{l})$ were added to $16 \mu 1$ of each enzyme standard reaction mixture and incubated at $37^{\circ} \mathrm{C}$ for $60 \mathrm{~min}$, except for Taq pol, which was incubated at $74^{\circ} \mathrm{C}$ for $60 \mathrm{~min}$. Activity without the inhibitor was considered $100 \%$, and the remaining activity at each concentration of the inhibitor was determined relative to this value. One unit of pol activity was defined as the amount of enzyme that catalyzed the incorporation of $1 \mathrm{nmol}$ of dNTP (i.e., dTTP) into synthetic DNA template-primer in $60 \mathrm{~min}$ at $37^{\circ} \mathrm{C}$ under the normal reaction conditions for each enzyme $(25,26)$

Other enzyme assays. DNA primase activity of pol $\alpha$ and the activities of T7 RNA polymerase, human DNA topoisomerases I and II, T4 polynucleotide kinase and bovine deoxyribonuclease I were measured using standard assays according to the manufacturer's specifications as described by Tamiya-Koizumi et al (28), Nakayama and Saneyoshi (29), Mizushina et al (30), Soltis and Uhlenbeck (31) and Lu and Sakaguchi (32), respectively.

\section{Results}

Effects of dehydroaltenusin and its analogues on the activities of mammalian pols $\alpha$ and $\beta$. First, the inhibitory effect of chemically synthesized dehydroaltenusin $\mathbf{1}$ and its analogues 2-7 (Fig. 1A) on mammalian pols $\alpha$ and $\beta$ was investigated. Dehydroaltenusin dose-dependently inhibited the activity of calf pol $\alpha$, with $50 \%$ inhibition observed at a dose of $0.68 \mu \mathrm{M}$ (Table I) and almost complete inhibition at $4 \mu \mathrm{M}$ (7). Although we reported previously that the naturally purified dehydroaltenusin from a fungus (Acremonium sp.) was a specific inhibitor of mammalian pol $\alpha(6)$, this compound was also effective at inhibiting rat pol $B$ with an $\mathrm{IC}_{50}$ value of $64 \mu \mathrm{M}$.

In the prepared dehydroaltenusin analogues 2-7, acetyldehydroaltenusin $\mathbf{2}$ and demethoxydehydroaltenusin $\mathbf{3}$ inhibited pol $\alpha$ and $\beta$ activities (Table I), and especially demethoxydehydroaltenusin was an $\sim 3$-fold stronger pol $\alpha$ inhibitor than dehydroaltenusin. The inhibitory effect of demethoxydehydroaltenusin on pol $\beta$ was $\sim 1$.4-fold weaker than that of dehydroaltenusin; therefore, the specificity of pol $\alpha$ inhibition by demethoxydehydroaltenusin was greater than that by dehydroaltenusin (i.e., the $\mathrm{IC}_{50}$ value ratio against pol $3 /$ pol $\alpha$ for demethoxydehydroaltenusin was 371, and for dehydroaltenusin, 94). Acetyl-dehydroaltenusin was a $>10$-fold weaker pol $\alpha$ inhibitor than dehydroaltenusin, and compounds 4-7 did not influence the activities of pols $\alpha$ and $\beta$.

Inhibitory effects of demethoxydehydroaltenusin derivatives on mammalian pols $\alpha$ and $\beta$ activities. Since the structural difference between dehydroaltenusin $\mathbf{1}$ and demethoxydehydroaltenusin $\mathbf{3}$ is the group at the 5-position of these compounds, four modified groups were synthesized chemically at the 5-position, 8-11, as shown in Fig. 1B. Fig. 2A shows the inhibition dose-response curves of demethoxydehydroaltenusin derivatives, and all compounds $(0-1 \mu \mathrm{M})$ dose-dependently inhibited the activity of calf pol $\alpha$. 
A

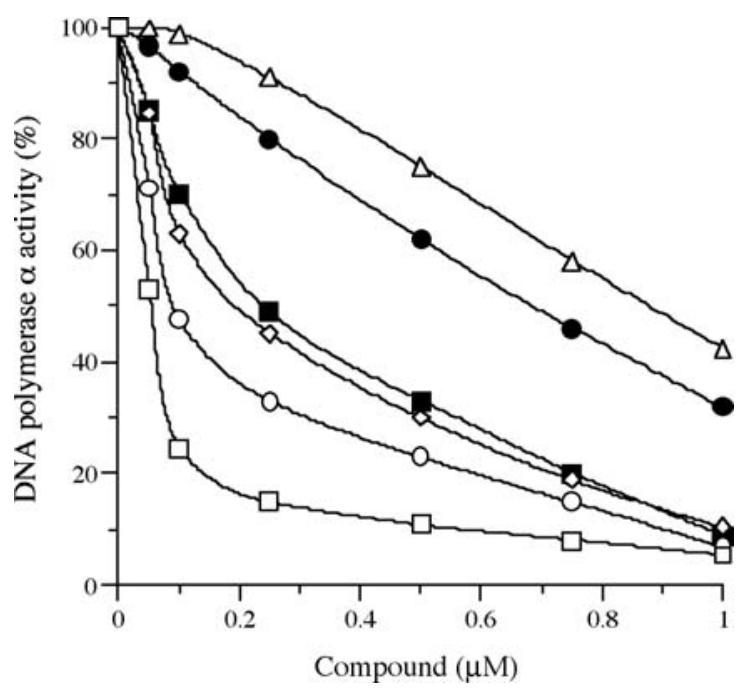

B

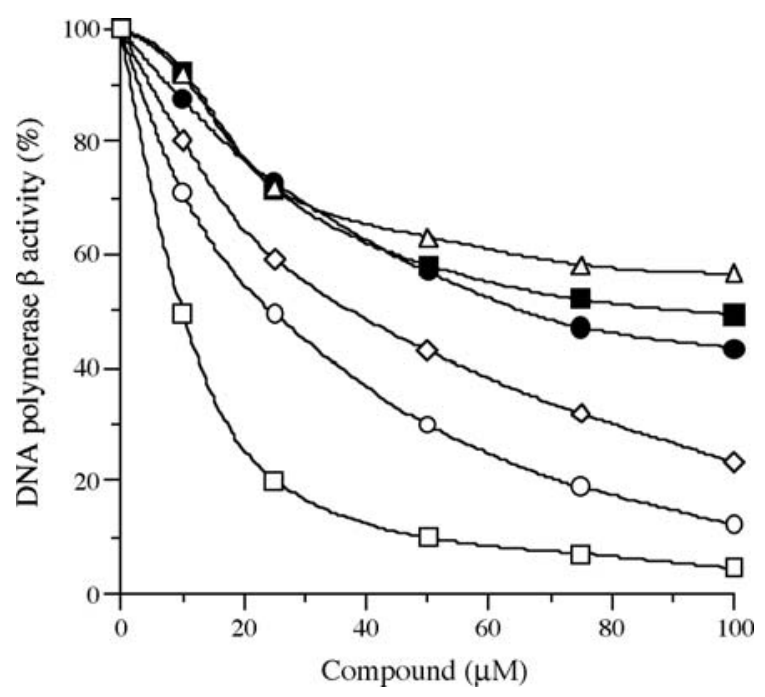

Figure 2. Dose-response curves of demethoxydehydroaltenusin derivatives. (A) Calf thymus pol $\alpha$ activity (0-1 $\mu \mathrm{M})$ and (B) rat recombinant pol $\mathrm{B}$ activity $(0-100 \mu \mathrm{M})$. 1, Dehydroaltenusin $(\bullet)$; 3, demethoxydehydroaltenusin $(\boldsymbol{\bullet}) ; \mathbf{8}$, demethyldehydroaltenusin $(\triangle)$; 9, dehydroaltenusin-C3 $(\diamond)$; 10, dehydroaltenusin-C6 $(\bigcirc)$; and 11, dehydroaltenusin-C12 $(\square)$. The amount of each enzyme in the assay mixture was 0.05 units. The enzymatic activity was measured as described in Materials and methods. Enzyme activity in the absence of the compound was taken as $100 \%$.

Dehydroaltenusin-C12 $\mathbf{1 1}$ had the strongest inhibitory effect among the compounds tested, and in order of their effect, the derivatives were ranked as follows: dehydroaltenusin-C12 11> dehydroaltenusin-C6 $10>$ dehydroaltenusin-C3 $9>$ demethoxydehydroaltenusin $\mathbf{3}>$ dehydroaltenusin $\mathbf{1}>$ demethyldehydroaltenusin $\mathbf{8}$.

On the other hand, the inhibitory effects on rat pol $\beta$ activity by all the compounds were weaker than those on calf pol $\alpha$, and the inhibitory effect of each derivative varied markedly in the following order: dehydroaltenusin-C12 11> dehydroaltenusin-C6 $10>$ dehydroaltenusin-C3 $9>$ dehydroaltenusin $\mathbf{1}>$ demethoxydehydroaltenusin $\mathbf{3}>$ demethyldehydroaltenusin 8 (Fig. 2B). The $\mathrm{IC}_{50}$ value ratio against pol B/ pol $\alpha$ ranked as follows: demethoxydehydroaltenusin $\mathbf{3}$ (371) > dehydroaltenusin-C6 10 (267) > dehydroaltenusinC3 9 (195) > dehydroaltenusin-C12 11 (180) > demethyldehydroaltenusin 8 (142) > dehydroaltenusin 1 (94). These results suggested that demethoxydehydroaltenusin $\mathbf{3}$ was the most specific pol $\alpha$ inhibitor of the synthesized derivatives, and the specificity of demethoxydehydroaltenusin was $\sim 4$-fold stronger than that of dehydroaltenusin; therefore, demethoxydehydroaltenusin was investigated for the inhibitory effects against other pol species and DNA metabolic enzymes in the later part of this study.

Effects of demethoxydehydroaltenusin on the activities of various pols and other DNA metabolic enzymes. The selective inhibition of demethoxydehydroaltenusin $\mathbf{3}$ was compared with that of dehydroaltenusin $\mathbf{1}$ and aphidicolin, which is a known inhibitor of replicative pols such as pols $\alpha, \delta$ and $\varepsilon$ (33). As shown in Table II, dehydroaltenusin and demethoxydehydroaltenusin were 94-fold and 371-fold, respectively, more effective against the activity of calf pol $\alpha$ than that of rat pol $\beta$. Dehydroaltenusin also inhibited human pol $\lambda$ activity, and the inhibitory concentration on pol $\lambda$ was almost the same as that for pol $ß$. On the other hand, demethoxydehydroaltenusin did not suppress other mammalian pols including pol $\lambda$; therefore, this compound could be a more potent pol $\alpha$ inhibitor than dehydroaltenusin.

Since aphidicolin exhibited inhibition of calf pol $\alpha$ with an $\mathrm{IC}_{50}$ value of $20 \mu \mathrm{M}$, the effect of demethoxydehydroaltenusin on this enzyme was $\sim 83$-fold stronger than that of aphidicolin (Table II). Aphidicolin also inhibited eukaryotic pol activities such as human pols $\delta$ and $\varepsilon$, fish (cherry salmon) pols $\alpha$ and $\delta$, and plant (cauliflower) pol $\alpha$, although dehydroaltenusin and demethoxydehydroaltenusin did not show any influence on these pols.

These three compounds had no inhibitory effect on human pols $\gamma, \eta, \iota$ and $\kappa$, prokaryotic pols such as the Klenow fragment of E. coli pol I (Klenow fragment), Taq pol and T4 pol, or other DNA metabolic enzymes such as calf primase of pol $\alpha$, HIV-1 reverse transcriptase, T7 RNA polymerase, human DNA topoisomerases I and II, T4 polynucleotide kinase and bovine deoxyribonuclease I (Table II). The $\mathrm{IC}_{50}$ values for pols in Tables I and II did not change when the DNA template-primer was activated DNA (i.e., doublestranded DNA) digested by deoxyribonuclease I instead of poly $(\mathrm{rA}) /$ oligo $(\mathrm{dT})_{12-18}$.

Demethoxydehydroaltenusin did not effect the thermal transition of melting temperature (data not shown); thus, none of the compound bound to double-stranded DNA, suggesting that this must inhibit enzyme activities by interacting with pol $\alpha$ directly. It was investigated whether an excessive amount of nucleic acid [i.e., poly( $(\mathrm{rC})]$ or protein [i.e., bovine serum albumin (BSA)] could prevent the inhibitory effect of demethoxydehydroaltenusin to determine whether the effect resulted from their non-specific adhesion to pol $\alpha$ or selective binding to specific sites. Poly(rC) and BSA had little or no influence on the effect of demethoxydehydroaltenusin, suggesting that the binding to pol $\alpha$ occurs selectively. 
Table II. $\mathrm{IC}_{50}$ values of demethoxydehydroaltenusin derivatives modified at the 5-position on the activities of various DNA polymerases and other DNA metabolic enzymes.

\begin{tabular}{|c|c|c|c|}
\hline \multirow[b]{2}{*}{ Enzyme } & \multicolumn{3}{|c|}{$\mathrm{IC}_{50}$ value $(\mu \mathrm{M})$} \\
\hline & 1 & 3 & Aphidicolin \\
\hline \multicolumn{4}{|l|}{ Mammalian DNA polymerases } \\
\hline Calf DNA polymerase $\alpha$ & 0.68 & 0.24 & 20 \\
\hline Rat DNA polymerase $\beta$ & 64 & 89 & $>100$ \\
\hline Human DNA polymerase $\gamma$ & $>100$ & $>100$ & $>100$ \\
\hline Calf DNA polymerase $\delta$ & $>100$ & $>100$ & 13 \\
\hline Human DNA polymerase $\varepsilon$ & $>100$ & $>100$ & 16 \\
\hline Human DNA polymerase $\eta$ & $>100$ & $>100$ & $>100$ \\
\hline Human DNA polymerase ı & $>100$ & $>100$ & $>100$ \\
\hline Human DNA polymerase $\kappa$ & $>100$ & $>100$ & $>100$ \\
\hline Human DNA polymerase $\lambda$ & 69 & $>100$ & $>100$ \\
\hline \multicolumn{4}{|l|}{ Fish DNA polymerases } \\
\hline Cherry salmon DNA polymerase $\alpha$ & $>100$ & $>100$ & 28 \\
\hline Cherry salmon DNA polymerase $\delta$ & $>100$ & $>100$ & 24 \\
\hline \multicolumn{4}{|l|}{ Plant DNA polymerases } \\
\hline Cauliflower DNA polymerase $\alpha$ & $>100$ & $>100$ & 32 \\
\hline Rice DNA polymerase $\lambda$ & $>100$ & $>100$ & $>100$ \\
\hline \multicolumn{4}{|l|}{ Prokaryotic DNA polymerases } \\
\hline E. coli DNA polymerase I (Klenow fragment) & $>100$ & $>100$ & $>100$ \\
\hline Taq DNA polymerase & $>100$ & $>100$ & $>100$ \\
\hline T4 DNA polymerase & $>100$ & $>100$ & $>100$ \\
\hline \multicolumn{4}{|l|}{ Other DNA metabolic enzymes } \\
\hline Calf DNA primase of DNA polymerase $\alpha$ & $>100$ & $>100$ & $>100$ \\
\hline HIV-1 reverse transcriptase & $>100$ & $>100$ & $>100$ \\
\hline T7 RNA polymerase & $>100$ & $>100$ & $>100$ \\
\hline Human DNA topoisomerase I & $>100$ & $>100$ & $>100$ \\
\hline Human DNA topoisomerase II & $>100$ & $>100$ & $>100$ \\
\hline T4 polynucleotide kinase & $>100$ & $>100$ & $>100$ \\
\hline Bovine deoxyribonuclease I & $>100$ & $>100$ & $>100$ \\
\hline
\end{tabular}

1, Dehydroaltenusin; 3, demethoxydehydroaltenusin. These compounds were incubated with each enzyme ( 0.05 units). The enzymatic activity was measured as described in Materials and methods. Enzyme activity in the absence of the compound was taken as $100 \%$.

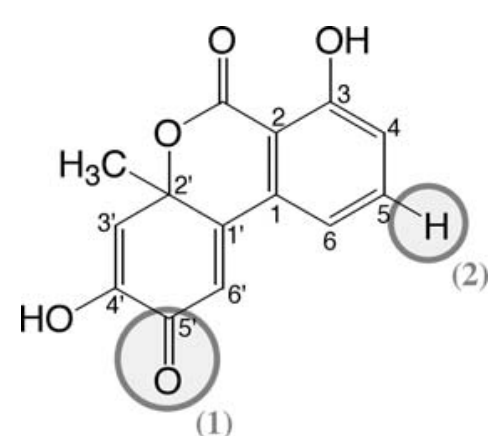

Figure 3. The chemical structure of a dehydroaltenusin derivative, demethoxydehydroaltenusin 3 , an inhibitor of mammalian pol $\alpha$. Groups (1) and (2) were essential for mammalian pol $\alpha$ inhibitory activity of the derivatives.
These results suggested that demethoxydehydroaltenusin, which is a derivative of dehydroaltenusin, could be a selective inhibitor of mammalian pol $\alpha$.

\section{Discussion}

We previously reported an inhibitor of mammalian pol $\alpha$ from a fungus, Acremonium sp., and this compound was dehydroaltenusin 1 (6). The inhibitory effect of dehydroaltenusin on pol $\alpha$ was 94 -fold stronger than that on pol $\beta$, and 10 derivatives 2-11 were prepared to screen for more potent pol $\alpha$ inhibitors than dehydroaltenusin.

As shown in Table I, compounds 1-3 inhibited pol $\alpha$ activity, but compounds 4-7 did not; therefore, the ketone group at the 5'-position (1 of Fig. 3), as contained by 
compounds 1-3 but not by compounds 4-7 in these analogues of dehydroaltenusin, must be essential for the inhibition. Since the specificity of pol $\alpha$ inhibitory activity of demethoxydehydroaltenusin $\mathbf{3}$ was higher than that of the other dehydroaltenusin derivatives (i.e., compounds $\mathbf{1}$ and 8-11) (Fig. 2), the group at the 5-position ( 2 of Fig. 3) could be important for the selective inhibition of pol species. These results show that the dehydroaltenusin derivative, which has no group at the 5-position (i.e., demethoxydehydroaltenusin 3 ) is the best inhibitor of mammalian pol $\alpha$.

Demethoxydehydroaltenusin-induced inhibition of calf pol $\alpha$ activity was competitive with the template-primer and non-competitive with the dNTP substrate (data not shown). BIAcore analysis demonstrated that this compound bound to the core domain of the largest subunit, p180, of mouse pol $\alpha$, which has catalytic activity (34), but did not bind to the smallest subunit or the DNA primase p46 of mouse pol $\alpha$ (35) (data not shown). These results suggested that the demethoxydehydroaltenusin molecule competes with the templateprimer molecule at its binding site on the catalytic domain of mammalian pol $\alpha$, binds to the site, and simultaneously disturbs dNTP substrate incorporation into the templateprimer. It was considered that demethoxydehydroaltenusin binds three-dimensionally in a special pocket in mammalian pol $\alpha$. The structural relationship between the pol $\alpha$ catalytic subunit and demethoxydehydroaltenusin should be investigated by NMR analysis and computer simulation similarly to our previous studies using fatty acids and pol $\beta$ (36-38). Such studies are currently in process.

Demethoxydehydroaltenusin will be used to elucidate the biochemical and biomedical functions of pol $\alpha$ from two different focal points; to understand the precise role of each pol in vivo, and to develop drug design strategies for cancer chemotherapy agents, as pol $\alpha$ is an essential enzyme for DNA replication and subsequently for cell division $(1,2)$. Inhibitors of mammalian pol $\alpha$ are not only molecular tools useful for analyzing pols as a 'chemical knockout agent' instead of 'gene knockout method', but should also be considered as a group of potentially useful cancer chemotherapy agents. Demethoxydehydroaltenusin did not influence the activities of mammalian pols $\delta$ and $\varepsilon$, which are other replicative pols, but also showed no effect on pol $\alpha$ of another vertebrate, cherry salmon. Demethoxydehydroaltenusin is a type of antibiotic produced by a fungus and is chemically stable under in vivo conditions, indicating that it may be useful for analyzing the replication system within cells and for clinical use. Aphidicolin, once believed to be a pol $\alpha$-specific inhibitor, is now known to also inhibit the activities of pols $\delta$ and $\varepsilon(5)$. No pol $\alpha$ inhibitors with such a limited spectrum of action have been reported to date, and demethoxydehydroaltenusin can be a key agent for analyzing both the in vitro and in vivo functions of pol $\alpha$ in more detail. Thus, this compound can be a useful tool with which to study the in vitro functions of pol $\alpha$ and as a molecular probe to distinguish the structure of pol $\alpha$.

\section{Acknowledgements}

This investigation was supported by a Grant-in-Aid for JSPS Research Fellowships for Young Scientists (I.K.), a Grant-in-
Aid for Kobe-Gakuin University Joint Research (A) (H.Y. and Y.M.) and a 'Life Science Center for Cooperative Research' Project for Private Universities: matching fund subsidy from MEXT (Ministry of Education, Culture, Sports, Science and Technology), 2006-2010 (H.Y. and Y.M.). Y.M. acknowledges a Grant-in-Aid for Young Scientists (A) (no. 19680031) from MEXT, Grants-in-Aid from the Nakashima Foundation (Japan), Foundation of Oil and Fat Industry Kaikan (Japan), and The Salt Science Research Foundation, no. 08S3 (Japan).

\section{References}

1. Kornberg A and Baker TA: DNA Replication. 2nd edition. W.D. Freeman and Co., New York, pp197-225, 1992.

2. Friedberg EC, Feaver WJ and Gerlach VL: The many faces of DNA polymerases: strategies for mutagenesis and for mutational avoidance. Proc Natl Acad Sci USA 97: 5681-5683, 2000.

3. So AG and Downey KM: Eukaryotic DNA replication. Crit Rev Biochem Mol Biol 27: 129-155, 1992.

4. Ikegami S, Taguchi T, Ohashi M, Oguro M, Nagano H and Mano Y: Aphidicolin prevents mitotic cell division by interfering with the activity of DNA polymerase- $\alpha$. Nature 275 : 458-460, 1978.

5. DePamphilis ML: DNA Replication in Eukaryotic Cells. Cold Spring Harbor Laboratory Press America, New York, 1996.

6. Mizushina Y, Kamisuki S, Mizuno T, Takemura M, Asahara H, Linn S, Yamaguchi T, Matsukage A, Hanaoka F, Yoshida S, Saneyoshi M, Sugawara F and Sakaguchi K: Dehydroaltenusin, a mammalian DNA polymerase $\alpha$ inhibitor. J Biol Chem 275: 33957-33961, 2000 .

7. Takahashi S, Kamisuki S, Mizushina Y, Sakaguchi K, Sugawara F and Nakata T: Total synthesis of dehydroaltenusin. Tetrahedon Lett 44: 1875-1877, 2003.

8. Kamisuki S, Takahashi S, Mizushina Y, Hanashima S, Kuramochi K, Kobayashi S, Sakaguchi K, Nakata T and Sugawara F: Total synthesis of dehydroaltenusin. Tetrahedron 60: 5695-5700, 2004.

9. Kamisuki S, Takahashi S, Mizushina Y, Sakaguchi K, Nakata T and Sugawara F: Precise structural elucidation of dehydroaltenusin, a specific inhibitor of mammalian DNA polymerase $\alpha$. Bioorg Med Chem 12: 5355-5359, 2004.

10. Hadfield A, Schweitzer H, Trova MP and Green K: Practical, large-scale synthesis of 2,2-dimethyl-5-hydroxy-4-oxo-benzo1,4-dioxin. Synth Commun 24: 1025-1028, 1994.

11. Dushin RG and Danishefsky SJ: Total syntheses of KS-501, KS-502, and their enantiomers. J Am Chem Soc 114: 655-659, 1992.

12. Li CC, Xie ZX, Zhang YD, Chen JH and Yang Z: Total synthesis of wedelolactone. J Org Chem 68: 8500-8504, 2003.

13. Kamisuki S, Murakami C, Ohta K, Yoshida H, Sugawara F, Sakaguchi K and Mizushina Y: Actions of derivatives of dehydroaltenusin, a new mammalian DNA polymerase $\alpha$ specific inhibitor. Biochem Pharmacol 63: 421-427, 2002.

14. Tamai K, Kojima K, Hanaichi T, Masaki S, Suzuki M, Umekawa H and Yoshida S: Structural study of immunoaffinity-purified DNA polymerase $\alpha$-DNA primase complex from calf thymus. Biochim Biophys Acta 950: 263-273, 1988.

15. Date T, Yamaguchi M, Hirose F, Nishimoto Y, Tanihara K and Matsukage A: Expression of active rat DNA polymerase $B$ in Escherichia coli. Biochemistry 27: 2983-2990, 1988.

16. Umeda S, Muta T, Ohsato T, Takamatsu C, Hamasaki N and Kang D: The D-loop structure of human mtDNA is destabilized directly by 1-methyl-4-phenylpyridinium ion $\left(\mathrm{MPP}^{+}\right)$, a parkinsonism-causing toxin. Eur J Biochem 267: 200-206, 2000.

17. Oshige M, Takeuchi R, Ruike R, Kuroda K and Sakaguchi K: Subunit protein-affinity isolation of Drosophila DNA polymerase catalytic subunit. Protein Expr Purif 35: 248-256, 2004.

18. Masutani C, Kusumoto R, Iwai S and Hanaoka F: Mechanisms of accurate translesion synthesis by human DNA polymerase $\eta$. EMBO J 19: 3100-3109, 2000.

19. Tissier A, Frank EG, McDonald JP, Iwai S, Hanaoka F and Woodgate R: Misinsertion and bypass of thymine-thymine dimers by human DNA polymerase ı. EMBO J 19: 5259-5266, 2000 . 
20. Ohashi E, Ogi T, Kusumoto R, Iwai S, Masutani C, Hanaoka F and Ohmori H: Error-prone bypass of certain DNA lesions by the human DNA polymerase к. Genes Dev 14: 1589-1594, 2000.

21. Shimazaki N, Yoshida K, Kobayashi T, Toji S, Tamai T and Koiwai O: Over-expression of human DNA polymerase $\lambda$ in $E$. coli and characterization of the recombinant enzyme. Genes Cells 7: 639-651, 2002.

22. Yamaguchi T, Saneyoshi M, Takahashi H, Hirokawa S, Amano R, Liu X, Inomata M and Maruyama T: Synthetic nucleoside and nucleotides. 43. Inhibition of vertebrate telomerases by carbocyclic oxetanocin G (C.OXT-G) triphosphate analogues and influence of C.OXT-G treatment on telomere length in human HL60 cells. Nucleosides Nucleotides Nucleic Acids 25: 539-551, 2006.

23. Sakaguchi K, Hotta Y and Stern H: Chromatin-associated DNA polymerase activity in meiotic cells of lily and mouse. Cell Struct Funct 5: 323-334, 1980.

24. Uchiyama Y, Kimura S, Yamamoto T, Ishibashi $\mathrm{T}$ and Sakaguchi K: Plant DNA polymerase $\lambda$, a DNA repair enzyme that functions in plant meristematic and meiotic tissues. Eur J Biochem 271: 2799-2807, 2004.

25. Mizushina Y, Tanaka N, Yagi H, Kurosawa T, Onoue M, Seto H, Horie T, Aoyagi N, Yamaoka M, Matsukage A, Yoshida S and Sakaguchi K: Fatty acids selectively inhibit eukaryotic DNA polymerase activities in vitro. Biochim Biophys Acta 1308: 256-262, 1996.

26. Mizushina Y, Yoshida S, Matsukage A and Sakaguchi K: The inhibitory action of fatty acids on DNA polymerase $\beta$. Biochim Biophys Acta 1336: 509-521, 1997.

27. Ogawa A, Murate T, Suzuki M, Nimura Y and Yoshida S: Lithocholic acid, a putative tumor promoter, inhibits mammalian DNA polymerase B. Jpn J Cancer Res 89: 1154-1159, 1998.

28. Tamiya-Koizumi K, Murate T, Suzuki M, Simbulan CG, Nakagawa M, Takamura M, Furuta K, Izuta S and Yoshida S: Inhibition of DNA primase by sphingosine and its analogues parallels with their growth suppression of cultured human leukemic cells. Biochem Mol Biol Int 41: 1179-1189, 1997.
29. Nakayama $C$ and Saneyoshi M: Inhibitory effects of 9-B-Dxylofuranosyladenine 5'-triphosphate on DNA-dependent RNA polymerase I and II from cherry salmon (Oncorhynchus masou). J Biochem 97: 1385-1389, 1985.

30. Mizushina Y, Murakami C, Ohta K, Takikawa H, Mori K, Yoshida H, Sugawara F and Sakaguchi K: Selective inhibition of the activities of both eukaryotic DNA polymerases and DNA topoisomerases by elenic acid. Biochem Pharmacol 63: 399-407, 2002.

31. Soltis DA and Uhlenbeck OC: Isolation and characterization of two mutant forms of T4 polynucleotide kinase. J Biol Chem 257: 11332-11339, 1982.

32. Lu BC and Sakaguchi: An endo-exonuclease from meiotic tissues of the basidiomycete Coprinus cinereus: Its purification and characterization. J Biol Chem 266: 21060-21066, 1991.

33. Oguro M, Suzuki-Hori C, Nagano H, Mano Y and Ikegami S: The mode of inhibitory action by aphidicolin on eukaryotic DNA polymerase $\alpha$. Eur J Biochem 97: 603-607, 1979.

34. Mizuno T, Yamagishi K, Miyazawa H and Hanaoka F: Molecular architecture of the mouse DNA polymerase $\alpha-$ primase complex. Mol Cell Biol 19: 7886-7896, 1999.

35. Mizuno T, Okamoto T, Yokoi M, Izumi M, Kobayashi A, Hachiya T, Tamai K, Inoue T and Hanaoka F: Identification of the nuclear localization signal of mouse DNA primase: nuclear transport of p46 subunit is facilitated by interaction with p54 subunit. J Cell Sci 109: 2627-2636, 1996.

36. Mizushina Y, Ohkubo T, Date T, Yamaguchi T, Saneyoshi M, Sugawara $\mathrm{F}$ and Sakaguchi K: Mode analysis of a fatty acid molecule binding to the N-terminal 8-kDa domain of DNA polymerase B. J Biol Chem 274: 25599-25607, 1999.

37. Mizushina Y, Ohkubo T, Sugawara F and Sakaguchi K: Structure of lithocholic acid binding to the N-terminal 8-kDa domain of DNA polymerase $B$. Biochemistry 39: 12606-12613, 2000 .

38. Mizushina Y, Sugawara F, Iida A and Sakaguchi K: Structural homology between DNA binding sites of DNA polymerase $B$ and DNA topoisomerase II. J Mol Biol 304: 385-395, 2000. 